\title{
ADSORPTION OF CADMIUM (II) FROM SIMULATED WASTEWATER USING ALBIZIA SAMANPOD ACTIVATED CARBON IN FIXED BED COLUMNS
}

\author{
G. D. Akpen ${ }^{1,}{ }^{*}$, M. I. Aho ${ }^{2}$ and N. Baba ${ }^{3}$

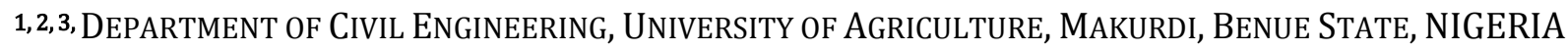 \\ Email addresses.1deliakpen@yahoo.com, 22aho_ped@yahoo.com, ${ }^{3}$ princebaban@yahoo.com
}

\begin{abstract}
The possibility of using Albizia saman pod activated carbon (ASPAC) as an adsorbent in fixed down flow adsorption columns to remove Cd (II) from wastewater was investigated for the purpose of converting the waste to a valuable product. The effects of impregnation ratio, particle size, carbon height, pressure head and initial cadmium Cd (II) concentration on the adsorption of Cd (II) from wastewater were investigated. The obtained adsorption data from the experiment was then fitted into the Hutchin's bed depth service time (BDST) model to study the columns performance at $15 \%$ and $90 \%$ breakthrough concentrations. The BDST model constants were determined. An optimal pressure head of $5 \mathrm{~cm}$, impregnation ratio of 1:6, packing height of $3.5 \mathrm{~cm}$, particle size of $75 \mu \mathrm{m}$ and initial Cd (II) concentration of $0.029 \mathrm{mg} / \mathrm{L}$ were found to be the most effective combination, which removed $100 \%$ of the Cd (II) within a service time of 14 hrs. There was a gradual decrease in the percentage of adsorbed Cd (II) with time; the percentage adsorbed became zero at 44, 56 and 86 hours respectively for $2.5 \mathrm{~cm}, 3 \mathrm{~cm}$ and $3.5 \mathrm{~cm}$ carbon heights. The breakthrough curves for Cd (II) adsorption maintained the characteristic S-curve for most dynamic studies. Chisquared test performed on the developed BDST models revealed the goodness of fit of the models for the prediction of the columns performance at all breakthrough concentrations investigated. The use of ASPAC as adsorbent for the removal of Cd (II) from wastewater in adsorption columns is therefore recommended.
\end{abstract}

Key words: Activated carbon, cadmium (II), fixed bed columns, Albizia saman pod, wastewater.

\section{INTRODUCTION}

Heavy metal contamination of water is one of the most important environmental problems all over the world. Hence, removal of toxic heavy metals from industrial wastewater is essential from the stand point of environmental pollution control and public health [14]. Current treatment processes adopted for metal contaminated wastewater streams include chemical precipitation, membrane filtration, ion exchange, carbon adsorption, coagulation-flocculation, flotation, electrochemical treatment, electro-dialysis, solvent extraction and freeze crystallization [5]. Adsorption has been reported to be one of the easiest, safest and most cost-effective methods for the removal of metals [6-8]. Activated carbon (AC) has been effectively used as an adsorbent for the removal of heavy metal pollutants from wastewater. The high cost of commercial AC has stimulated interest in examining the feasibility of using cheaper raw materials. Activated carbons of biological origin have been used for the removal of heavy metals from aqueous solution [9-12]. Agricultural adsorbents such as coffee husk [13], peanut shells [14], mango seed shell [15], bagasse [16], rice husk [17], sawdust [18] and sorghum bicolor stalk [19] among others have also been successfully used for the removal of various pollutants from water.

The adsorption of lead $\left(\mathrm{Pb}^{2+}\right)$, copper $\left(\mathrm{Cu}^{2+}\right)$ and zinc $\left(\mathrm{Zn}^{2+}\right)$ on sawdust in fixed bed columns was studied by [20]. They reported that the most favourably sorbed metal, $\mathrm{Pb}^{2+}$, occupied most of the adsorption sites on the sawdust in the column. Therefore, less favourably sorbed metals such as $\mathrm{Cu}^{2+}$ and $\mathrm{Zn}^{2+}$ showed more rapid breakthrough.

The removal of colour, copper and chromium from electroplating wastewater in adsorption columns using materials such as wood charcoal, coconut shell carbon and activated alumina was studied by [21]. Activated alumina was reported to be better than the other carbons based on the amount of pollutants removed.

The effect of bed height and flow rate on bio-sorption process was investigated by [22] in fixed-bed columns. The obtained results showed that the maximum break- 
through time of 320 min was achieved at the operating condition of $2 \mathrm{ml} / \mathrm{min}$ and $8 \mathrm{~cm}$ influent flow rate and bed height, respectively.

The efficiency of coconut husks $(\mathrm{CH})$ in removing methylene blue (MB) dye from wastewaters in a fixed bed adsorption column was assessed by [23]. The adsorbent $(\mathrm{CH})$ was prepared using $\mathrm{NaOH}$ as the activating agent and three different column bed depths of 10,20 , and $25 \mathrm{~cm}$. The breakthrough time and exhaustion time increased with increasing bed depth and the adsorption capacity of $\mathrm{CH}$ on $\mathrm{MB}$ increased slightly with increasing column bed depth. This, they explain was probably due to the increase in the surface area of the adsorbent and the extended contact time with the MB solution.

Activated Carbon from mango seed shell was used in adsorption column for the removal of chromium from wastewater by [24]. They reported that breakthrough curves for chromium adsorption deviated from the characteristic S-curve for most dynamic studies and the developed BDST models predicted the column performance better at lower breakthrough concentrations.

Little information is however available on the use of Albizia saman pod as an adsorbent for the removal of pollutants from wastewater; although the potential for its use has been recognized [25]. Albizia saman pods are renewable agricultural wastes available abundantly at little or no cost. The use of Albizia saman pods as AC will reduce solid wastes in the environment. Besides, Cd (II) is of public health concern because of its carcinogenic and other toxic effects such as itai-itai disease, skin ulceration and liver and kidney damage in animals and humans [26]. Effluents from industries such as phosphate fertilizer contain cadmium. The effective removal of $\mathrm{Cd}$ (II) from such industrial wastewater is essential to protect public health. The aim of this study therefore is to prepare AC from Albizia saman pod and investigate its efficiency and effectiveness in the removal of Cd (II) from wastewater in adsorption columns.

\subsection{Theoretical: BDST Model}

In fixed bed systems, the main design criterion is to predict the service time of the bed, that is, how long the adsorbent material will be effective in removing a specified amount of pollutant from water before regeneration or replacement is needed. The bed depth service time (BDST) model [27], is one of the models that offer simplified approach and rapid prediction of adsorber performance. The linearized form of this relationship is given as [27]:

$$
\mathrm{t}=\frac{\mathrm{N}_{\mathrm{o}} \mathrm{H}}{\mathrm{C}_{\mathrm{o}} \mathrm{F}}-\frac{1}{\mathrm{kC}_{\mathrm{o}}} \ln \left(\frac{\mathrm{C}_{\mathrm{o}}}{\mathrm{C}_{\mathrm{b}}}-1\right)
$$

Where: $\mathrm{t}$ is service time (hrs) to breakthrough; $\mathrm{N}_{o}$ is adsorption capacity ( $\mathrm{mg}$ solute/L adsorbent); $\mathrm{C}_{o}$ is initial solute concentration ( $\mathrm{mg} / \mathrm{L}) \mathrm{F}$ is linear flow rate $(\mathrm{m} / \mathrm{h}) ; \mathrm{H}$ is depth of adsorbent bed $(\mathrm{m}) ; \mathrm{k}$ is rate constant of adsorption (L/mg.h) and $\mathrm{C}_{b}$ is outlet concentration at the desired breakthrough level $(\mathrm{mg} / \mathrm{L}) . \mathrm{N}_{\mathrm{o}}$ and $\mathrm{k}$ are evaluated from the slope and intercept at $t=0$ of the graph of $t$ against $H$. The critical bed depth $\left(\mathrm{H}_{\mathrm{o}}\right)$ of the column, which theoretically, is just sufficient to prevent concentration in excess of $C_{b}$ at $\mathrm{t}=0$, is determined from Equation (1) when $\mathrm{t}=0$ thus:

$$
\mathrm{H}_{\mathrm{o}}=\frac{\mathrm{F}}{\mathrm{kN}_{\mathrm{o}}} \ln \left(\frac{\mathrm{C}_{\mathrm{o}}}{\mathrm{C}_{\mathrm{b}}}-1\right)
$$

Only three fixed bed tests are required to collect the necessary data required for BDST analysis [28], instead of nine columns required by the approach of [29] thus saving time and money. In addition, with the Hutchins approach, if a value of the slope for one flow rate is obtained, values for other flow rates can be computed by multiplying the original slope by the ratio of the original and new flow rates. The intercept, $b$, value change is insignificant with respect to changing flow rates. Adjustment for changing initial concentration can also be made as follows [28]:

$$
\begin{gathered}
a_{2}=a_{1} \frac{C_{1}}{C_{2}} \\
b_{2}=b_{1} \frac{C_{1}\left[\ln \left(\frac{C_{2}}{C_{f}}-1\right)\right]}{C_{1}\left[\ln \left(\frac{C_{1}}{C_{b}}-1\right)\right]}
\end{gathered}
$$

Where: $\mathrm{C}_{1}$ and $\mathrm{C}_{2}$ are the experimental initial concentration and any given initial concentration (assumed or desired), respectively.

$\mathrm{C}_{\mathrm{f}}$ and $\mathrm{C}_{\mathrm{b}}$ are the effluent concentrations with respect to $\mathrm{C}_{2}$ and $\mathrm{C}_{1}$ respectively. But for a fixed breakthrough effluent concentration, $\mathrm{C}_{\mathrm{f}}=\mathrm{C}_{\mathrm{b}}$, hence (4) can be used to evaluate $b_{2}$. $a_{1}$ and $a_{2}$ are the slopes of the plot of $t$ against $H$ with respect to $C_{1}$ and $C_{2}$, respectively. $b_{1}$ and $b_{2}$ are the intercepts of the plot of $t$ against $H$ with respect to $C_{1}$ and $C_{2}$, respectively.

\section{MATERIALS AND METHODS}

\subsection{Preparation of Adsorbent}

The Albizia saman pods were collected within the University of Agriculture, Makurdi, Benue State, Nigeria and air-dried. The air-dried Albizia saman pods were broken to remove the seeds. The free pods were thoroughly washed with water to remove any dirt, airdried and cut into sizes of $2-4 \mathrm{~cm}$ before carbonization. The carbonization was performed in a 
muffle furnace (model; ME 45/12 sob) by Arnold Schröder (industrieöfen $\mathrm{GmbH}$ ), Germany. This was done according to a modified form of the method described by [30]. Nine hundred grams (900 g) of the air-dried sample (Albizia saman pod) were weighed into clean stainless steel containers and placed in the furnace at a pre-set temperature of $500^{\circ} \mathrm{C}$ for $360 \mathrm{mins}$. Standard solutions of $\mathrm{ZnCl}_{2}(0.25 \mathrm{M}, 0.5 \mathrm{M}, 0.75 \mathrm{M}, 1 \mathrm{M}$, and $1.25 \mathrm{M}$ ) were prepared by dissolving $34.073 \mathrm{~g}$, $68.145 \mathrm{~g}, 102.22 \mathrm{~g}, 136.29 \mathrm{~g}$, and $170.36 \mathrm{~g}$ of anhydrous $\mathrm{ZnCl}_{2}$ in $1000 \mathrm{~mL}$ of distilled water. The carbons were then impregnated using the $\mathrm{ZnCl}_{2}$ solutions thus resulting in the various impregnation ratios of $1: 12$, $1: 6,1: 4,1: 3$, and $1: 2$ respectively. Details of the preparation procedure and characterisation of the produced Albizia saman pod activated carbon (ASPAC) are reported elsewhere [25, 31]. The activated carbons were crushed and sieved through sieve sizes 850, 600, 425, 300, 150 and $75 \mu \mathrm{m}$ and those retained on sieve, $75,150,300,425$ and $600 \mu \mathrm{m}$, were used for adsorption studies.

\subsection{Wastewater Sample Preparation}

Stock solution $(0.08 \mathrm{mg} / \mathrm{L})$ of $\mathrm{Cd}$ was prepared by dissolving $10 \mathrm{mg}$ of cadmium acetate, $\left(\mathrm{Cd}\left(\mathrm{CH}_{3} \mathrm{CO}_{2}\right)_{2}\right)$ in $100 \mathrm{~mL}$ of de-ionised water. The stock solution was further diluted with distilled water to desired concentrations to obtain standard solutions for absorbance measurement using spectrophotometer (model DR 2000, HACH). The sample solutions which were treated with the adsorbent were similarly prepared by dissolving the required quantity of the $\mathrm{Cd}$ $\left(\mathrm{CH}_{3} \mathrm{CO}_{2}\right)_{2}$ in distilled water.

\subsection{Column Adsorption Studies}

The column adsorption experiment was performed in a plastic column of $50 \mathrm{~mm}$ diameter and $400 \mathrm{~mm}$ height. A known amount (in grams) of carbon under study was carefully transferred into the plastic column packed with cotton wool at the bottom to prevent the escape of the carbon particles with the effluent. The water sample to be treated was poured in a 4 litre capacity plastic container fitted with a tap at the bottom to which a $16 \mathrm{~mm}$ plastic pipe was connected. This was connected to another 4 litre capacity plastic container, also fitted with a tap at the bottom to which a $16 \mathrm{~mm}$ plastic pipe was connected and led to the top of the plastic column. Distilled water was passed through the column to ensure close packing of carbon particles before commencement of treatment. The flow through the columns was gravitational. A schematic diagram of the experimental column is shown in Figure 1.

\subsection{Water Quality Analysis}

The concentrations of cadmium (II) before and after specified time intervals of treatment with ASPAC were determined by using Direct Reading Spectrophotometer, (model DR/2000, HACH) according to the standard procedures prescribed in the manual. The dimensionless concentration was calculated according to Equation (5) thus:

$$
\text { Dimensionless concentration }=\frac{C t}{C_{0}}
$$

Where $\mathrm{C}_{0}$ is the initial cadmium (II) concentration $(\mathrm{mg} / \mathrm{L}), \mathrm{C}_{\mathrm{t}}$ is the cadmium concentration at any service time, $\mathrm{t}$ (hrs).

\subsection{Effect of Some Operational Parameters on the Adsorption of Cd (II) Ions}

The factors that influence adsorption such as impregnation ratio, initial concentration of adsorbate, carbon height, pressure head, and particle size were investigated. There was no scientific reason for the choice of the values of the parameters investigated except to vary them and observe the performance of the column in order to determine the optimum values. The effect of impregnation ratio was investigated by varying the impregnation ratios, $(1: 12,1: 6,1: 4,1: 3$, and $1: 2$ ) of ASPAC, while keeping other parameters (initial concentration $=0.039 \mathrm{mg} / \mathrm{L}$, particle size $=600 \mu \mathrm{m}$, carbon height $=2 \mathrm{~cm}$ and pressure head $=20 \mathrm{~cm}$ ) constant. The optimum impregnation ratio was adopted for further studies. Particle size effect on the adsorption of Cd (II) onto ASPAC was investigated by varying the particle sizes $(75,150,300,425$ and 600 $\mu \mathrm{m})$, while keeping other parameters constant.

The dependence of Cd (II) adsorption on carbon height was studied by varying the adsorbent heights (1.5, 2, $2.5,3$ and $3.5 \mathrm{~cm}$ ) in the column while keeping other parameters constant. The effect of pressure head on the adsorption of Cd (II) onto ASPAC was investigated by varying the pressure heads $(5,10,15,20$, and $25 \mathrm{~cm})$ while keeping other parameters constant. Initial inlet concentrations of Cd (II) of 0.029, 0.039, 0.049, 0.059, and $0.069 \mathrm{mg} / \mathrm{L}$, were adopted while maintaining a constant bed height, impregnation ratio, particle size and pressure head to determine the effect of inlet concentration on the column performance.

The obtained optimum values of all the operating variables were then used to treat the simulated wastewater in the fixed down flow columns and the generated data were used for BDST analysis to predict the columns performance at the optimum conditions. 


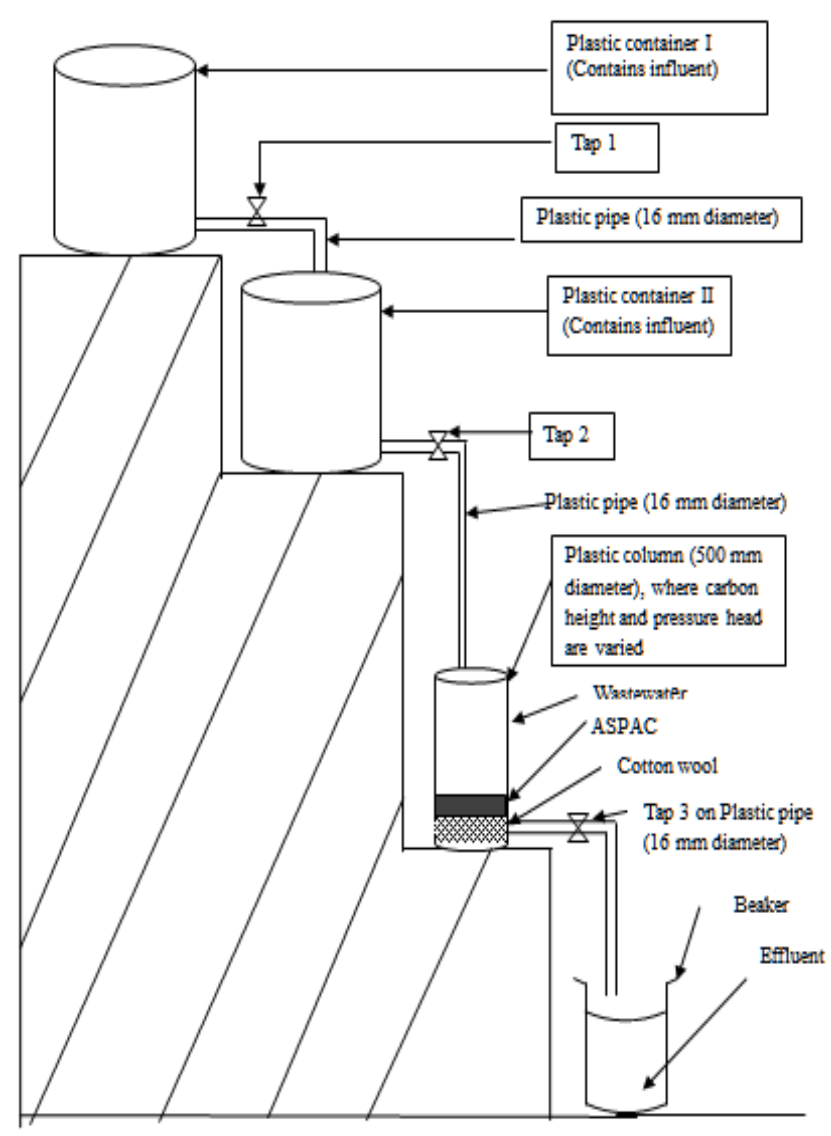

Figure 1: Schematic Diagram of Experimental Column.

\subsection{Data Analysis}

The data generated from the column studies were used to develop BDST models at breakthrough concentrations of $15 \%, 30 \%, 40 \%, 50 \%, 60 \%, 80 \%$ and $90 \%$, respectively. The validity of the models was verified using Chi-squared $\left(\chi^{2}\right)$ test according to Equation (6):

$$
x^{2}=\Sigma\left(O_{i}-E_{i}\right)^{2} / E_{i}
$$

Where, $\mathrm{O}_{\mathrm{i}}$ is the observed service time of the column and $E_{i}$ is the predicted service time of the column using the developed BDST models. Microsoft excel 2010 was used to analyse the data generated from the adsorption column experiments.

\section{RESULTS AND DISCUSSIONS}

\subsection{Effect of Impregnation Ratio}

The dimensionless concentrations, $C_{t} / C_{0}$ (where $C_{0}$ is the initial concentration of $\mathrm{Cd}$ (II) and $\mathrm{C}_{t}$ is the concentration remaining at any given service time) were plotted against service time, $t$, for the adsorption of Cd (II) on the ASPAC for five different impregnation ratios(IR) and the breakthrough curves obtained are presented in Figure 2. The curve corresponding to impregnation ratio of $1: 6$ is the lowest and is closely followed by impregnation ratio of $1: 4$ on top. The topmost curve is that corresponding to impregnation ratio of 1:2. It is important to emphasise that the lower the breakthrough curve, the better the performance of the ASPAC because the amount of $\mathrm{Cd}$ (II) remaining, $\mathrm{C}_{\mathrm{t}}$, is lower (i.e. amount adsorbed or removed is higher). It follows that among the five impregnation ratios investigated, that of 1:6 yielded the maximum $\mathrm{Cd}$ (II) removal. The impregnation ratio of 1:6 was therefore adopted as the optimum impregnation ratio. A study by [32] also produced a similar result in which the increased ratio of $\mathrm{ZnCl}_{2}$ resulted in a corresponding increase in surface area and hence adsorptive ability of AC. According [33] when IR was increased, the surface area and adsorption capacity of activated carbon derived from rice husks prepared by $\mathrm{KOH}$ chemical activation also increased.

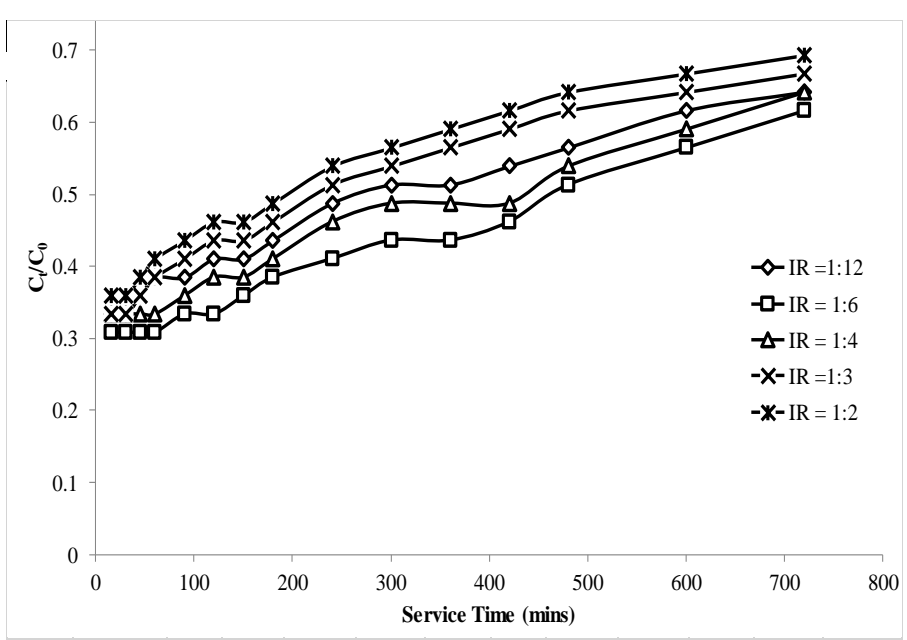

Figure 2: Breakthrough Curves for Various Impregnation Ratios

\subsection{Particle Size Effect}

The breakthrough curves of the adsorption of Cd (II) onto the ASPAC for the five different carbon particle sizes investigated are presented in Figure 3 . The bottom and the topmost curves represent the least and most effective particles sizes, respectively, in terms of Cd (II) removal using the ASPAC. There is a general decrease in Cd (II) removal with increase in particle size. Particle size of $75 \mu \mathrm{m}$ had the highest Cd (II) removal throughout the entire service time. While the lowest removal was recorded using particle size of 600 $\mu \mathrm{m}$ (top most curve). This observation is due to the decrease in the surface area for adsorption as carbon diameter increases [34]. Another explanation is the increase in diffusion path due to the larger diameter of particles. The particle size of $75 \mu \mathrm{m}$ was therefore the optimum particle size because it gave the highest removal of $\mathrm{Cd}$ (II) ions compared to other particle sizes. 


\subsection{Effect of Carbon Height}

Higher uptake was observed at higher bed heights due to the increase in the amount of the adsorbent which provided more adsorption sites for the adsorption process to proceed (Figure 4). The increase in bed height increased the mass transfer zone. The mass transfer zone in the column moved from the entrance of the bed and proceeded towards the exit. Hence for the same influent concentration and fixed-bed system, an increase in bed height would create a longer distance for the mass transfer zone to reach the exit, subsequently, resulting in extended breakthrough time. From the breakthrough curves in Figure 4, it was observed that the breakthrough time increased with increasing bed height. At $40 \%$ breakthrough for instance, the service time at the bed height of 1.5, 2, 2.5 and $3 \mathrm{~cm}$ were 81, 280, 480 and 600 mins, respectively. The removal efficiency of the adsorbent generally improved with increasing height. At a service time of 300 mins for instance, Cd (II) removal was 56.4, 69.2, $76.9,82,92.3 \%$ at $1.5,2,2.5,3,3.5 \mathrm{~cm}$ carbon heights respectively. This increase in percentage adsorbed with carbon height is expected because; the surface area available for adsorption increased with increase in the amount of the adsorbent (more binding sites were available for sorption with increase in bed height). Similar observations have been reported by other researchers $[23,35,36]$. The carbon height of $3.5 \mathrm{~cm}$ was therefore achieved as the optimum height because it has yielded the maximum Cd (II) removal.

\subsection{Effect of Pressure Head}

From the breakthrough curves in Figure 5, the pressure head of $5 \mathrm{~cm}$ yielded the maximum Cd (II) removal compared to other pressure heads investigated. The observed trend shows that at a higher pressure head, the front of the adsorption zone quickly reached the top of the column. That is, the column was saturated early. At a higher pressure head, a steeper curve with a relatively early breakthrough and exhaustion time resulted in lesser adsorbed amount of Cd (II). A lower pressure head resulted in a longer contact time as well as shallow adsorption zone. Therefore, the pressure head of $5 \mathrm{~cm}$ was the optimum pressure head.

\subsection{Effect of Initial Concentration}

The breakthrough time was found to decrease with increasing initial concentration as the binding sites saturated quicker. A decrease in inlet concentration gave an extended breakthrough time, indicating that a higher volume of solution could be treated (Figure 6). This could be explained by the fact that a lower concentration gradient caused a slower transport due to a decrease in diffusion coefficient or mass transfer coefficient. A similar trend was reported by [37] in the removal of methylene blue by Jack fruit -peel. This is because a given mass of adsorbent material can only remove a fixed amount of adsorbate [38]. The initial concentration of $0.029 \mathrm{mg} / \mathrm{L}$ was achieved as the optimum initial concentration because a higher volume of solution was treated per given time. In order words, the service time increased with decrease in initial $\mathrm{Cd}$ (II) concentration.

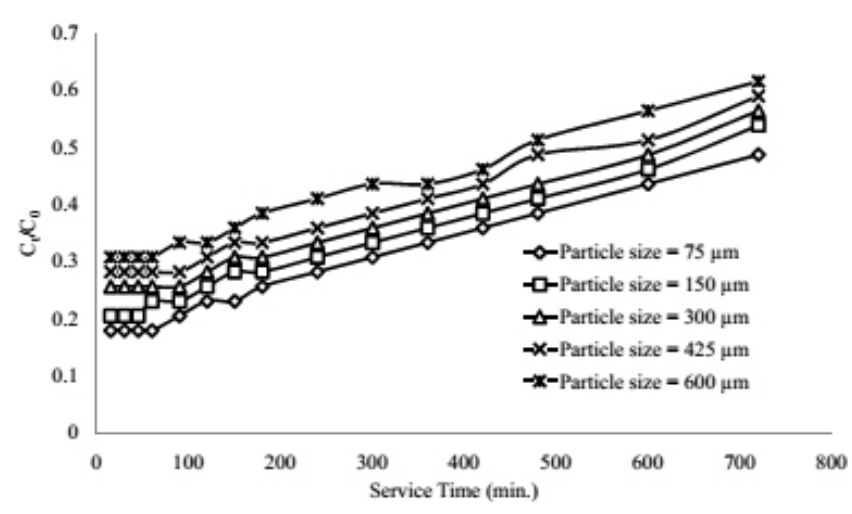

Figure 3: Breakthrough Curves for the various Particle Sizes.

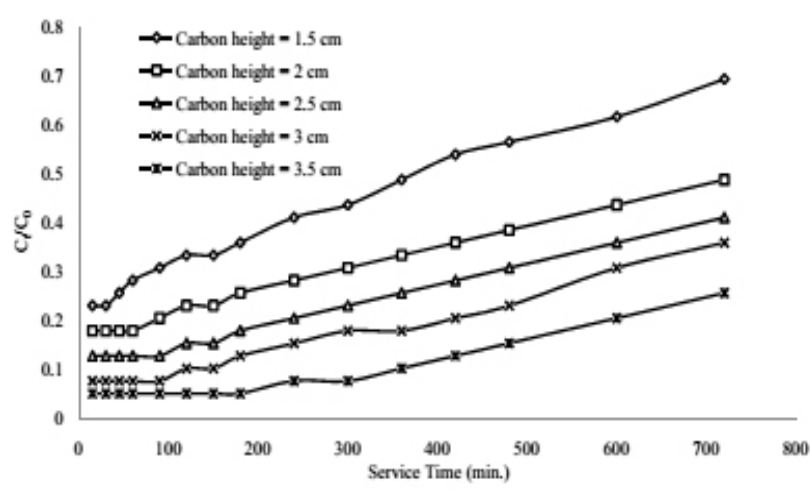

Figure 4: Breakthrough Curves for Various Carbon Heights

\subsection{Breakthrough Curves at the Optimum Operating Conditions}

The adsorption breakthrough curves shown in Figure 7 showed similar S-shape characteristic as reported for most dynamic adsorption studies in water and wastewater treatment [23] and [39]. The breakthrough and exhaustion points were assumed to be $15 \%(0.004$ $\mathrm{mg} / \mathrm{L})$ and $90 \%(0.026 \mathrm{mg} / \mathrm{L})$ of the initial influent concentration $(0.029 \mathrm{mg} / \mathrm{L})$, respectively. As shown in Figure 7, the exhaustion time increased with increasing bed height from 44 to 86 hrs as more adsorption sites were available for sorption and also resulted in a broadened mass transfer zone. As the feed solution continued to pass through the adsorbent bed, the 
carbon adsorption sites continued to reduce, and this led to increase in the concentration of Cd (II) in effluent with time. At the bed depth of $2.5 \mathrm{~cm}$ for instance, breakthrough and exhaustion points were reached after 12 hours and 44 hours, respectively.

\subsection{Bed Depth Service Time (BDST) Model}

The BDST models at various breakthrough concentrations and their corresponding constants are listed in Table 1. The BDST rate constant, $\mathrm{K}_{\mathrm{a}}$ and the critical bed depth, $\mathrm{H}_{0}$, decreased while adsorption capacity of the bed per unit bed volume, $\mathrm{N}_{0}$, increased with increase in breakthrough percentage. The high values of the coefficient of determination, $\mathrm{R}^{2}$ ( 0.964 and 0.990 at $15 \%$ and $90 \%$ breakthrough, respectively for instance), indicated the reliability of BDST model for the prediction of the adsorbent performance in the columns. The results of chi-squared test performed to confirm the validity of the developed BDST models are presented in Table 2. The test revealed that all the models showed good fit to the generated data because the calculated $\chi^{2}$ values were less than the tabulated values both at $5 \%$ and $1 \%$ levels of significance.

\section{CONCLUSION}

The adsorption of Cd (II) from aqueous solution onto ASPAC was investigated in fixed down flow adsorption columns. The breakthrough curves for the column adsorption of Cd (II) from solutions using ASPAC were developed at various impregnation ratios, particle sizes, carbon heights, pressure heads, and initial Cd (II) concentrations.

An optimal pressure head of $5 \mathrm{~cm}$, packing height of 3.5 $\mathrm{cm}$, particle size of $75 \mu \mathrm{m}$, impregnation ratio of $1: 6$ and initial Cd (II) concentration of $0.029 \mathrm{mg} / \mathrm{L}$ was found to be the most effective combination, which removed $100 \%$ of the Cd (II) within a service time of $14 \mathrm{hrs}$. The results showed that Cd (II) removal was significantly affected by both carbon height and service time.

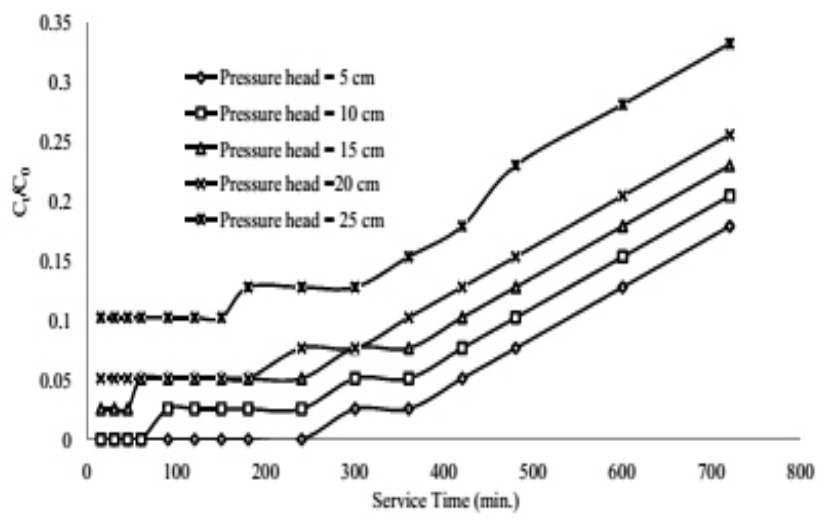

Figure 5: Breakthrough Curves for various Pressure Heads

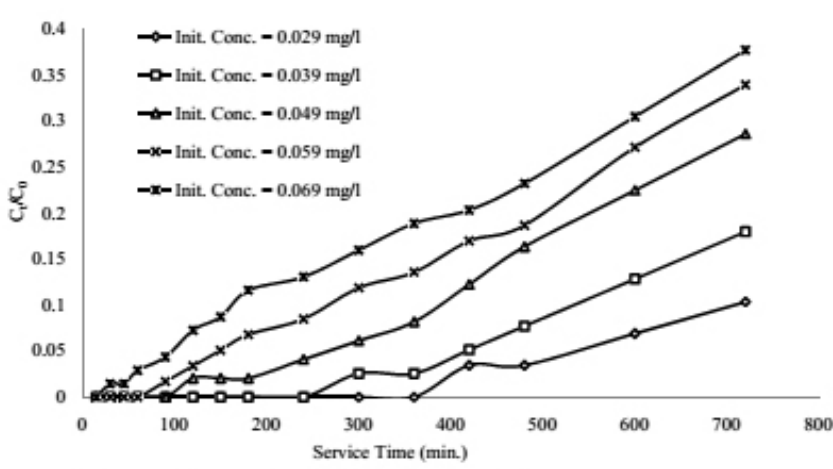

Figure 6: Breakthrough Curves for various Initial Concentrations



Figure 7: Breakthrough Curves for Cadmium Adsorption on ASPAC at Optimum Operating Conditions.

Table 1: Bed Depth Service Time (BDST) Models

\begin{tabular}{ccccccc}
\hline$\%$ & BDST Model & $\begin{array}{c}\mathrm{N}_{0} \\
(\mathrm{mg} / \mathrm{L})\end{array}$ & $\begin{array}{c}\mathrm{K}_{\mathrm{a}} \\
(\mathrm{l} / \mathrm{mg} . \mathrm{h})\end{array}$ & $\begin{array}{c}\mathrm{F} \\
(\mathrm{l} / \mathrm{h})\end{array}$ & $\begin{array}{c}\mathrm{H}_{0} \\
(\mathrm{~cm})\end{array}$ & $\mathrm{R}^{2}$ \\
\hline 15 & $\mathrm{t}=18 \mathrm{H}-34$ & 1.5159 & 1.8586 & 1.884 & 1.8889 & 0.964 \\
30 & $\mathrm{t}=20 \mathrm{H}-30.66$ & 1.6843 & 0.8981 & 1.884 & 1.5329 & 0.986 \\
40 & $\mathrm{t}=20 \mathrm{H}-28.66$ & 1.6843 & 0.4191 & 1.884 & 1.4329 & 0.986 \\
50 & $\mathrm{t}=20 \mathrm{H}-26.66$ & 1.6843 & -0.0892 & 1.884 & 1.3336 & 0.986 \\
60 & $\mathrm{t}=20 \mathrm{H}-24.66$ & 1.6843 & -0.4871 & 1.884 & 1.2329 & 0.986 \\
80 & $\mathrm{t}=22 \mathrm{H}-26$ & 1.8528 & -1.7821 & 1.884 & 1.1818 & 0.975 \\
90 & $\mathrm{t}=24 \mathrm{H}-26.66$ & 2.0212 & -2.7931 & 1.884 & 1.1108 & 0.990 \\
\hline
\end{tabular}


Adsorption of Cadmium (II) From Simulated Wastewater Using Albizia Saman Pod Activated Carbon, ... G. D. Akpen, et al.

Table 2: Chi-Squared Test Results at various Breakthrough Concentrations

\begin{tabular}{llllllll}
\hline $\mathrm{H}(\mathrm{cm})$ & $15 \%$ & $30 \%$ & $40 \%$ & $50 \%$ & $60 \%$ & $80 \%$ & $90 \%$ \\
\hline 2.5 & 0.0909 & 0.0225 & 0.0204 & 0.0187 & 0.0172 & 0.0345 & 0.0131 \\
3 & 0.2 & 0.0612 & 0.0573 & 0.0539 & 0.0508 & 0.1 & 0.0396 \\
3.5 & 0.0345 & 0.0111 & 0.0105 & 0.0101 & 0.0096 & 0.0196 & 0.0076 \\
$\chi^{2}$ & 0.3254 & 0.0948 & 0.0882 & 0.0826 & 0.0776 & 0.1541 & 0.0603 \\
\hline
\end{tabular}

Note: (i) Degree of freedom = 3-1 = 2; (ii) Chi-squared values from [40] are 5.99 and 9.21 at $5 \%$ and $1 \%$ significant levels respectively.

The [27] BDST model was used to study the columns performance at different breakthrough concentrations. The high values of the coefficient of determination, $\mathrm{R}^{2}$ (0.964 and 0.990 at $15 \%$ and $90 \%$ breakthrough, respectively), indicated the validity of BDST model for the present system. Chi-squared test performed to verify the validity of the developed BDST models revealed that the models predicted the columns performance reliably given that, the calculated $\chi^{2}$ values were less than the tabulated values both at $5 \%$ and $1 \%$ levels of significance. Based on the results of this study, the ASPAC appears a potential adsorbent in fixed down flow adsorption columns for the removal $\mathrm{Cd}$ (II) from wastewater. However, the data used in constructing BDST models in this research, were obtained using simulated solutions instead of live wastewater. Studies using live wastewater should be conducted to investigate the effect of interference from other impurities in industrial effluents.

\section{REFERENCES}

[1] Puranik, P. R. and Paknikar, K. M. "Biosorption of Lead, Cadmium and Zinc by Citrobacter Strain MCM B-181. Characterization Studies" Biotechnology Progress, Vol. 15, No.2, pp. 228237, 1999.

[2] Yan, G. and Viraraghavan, T. "Heavy Metal Removal from Aqueous Solution by Fungus Mucor rouxii", Water Research, Vol.37, No.18, pp 44864496, 2003.

[3] Abdel-Ghani, N. T.; Elchaghaby, G. A. "Influence of Operating Conditions On the Removal of $\mathrm{Cu}, \mathrm{Zn}$, $\mathrm{Cd}$ (II) and $\mathrm{Pb}$ Ions from Wastewater by Adsorption", International Journal of Environmental Science and Technology,Vol.4, No.4, pp 451-456, 2007.

[4] Abdel-Ghani, N. T.; Hegazy, A. K.; El-Chaghaby, G. A. "Typhadomingensis Leaf Powder for Decontamination of Aluminium, Iron, Zinc and Lead: Biosorption Kinetics and Equilibrium Modelling", International Journal of Environmental Science and Technology, Vol.6, No.2, pp 243-248, 2009.

[5] Bailey, S. E., Olin, T. J. and Bricka, R. M. and Adrian, D. D. "A Review of Potentially Low-Cost
Sorbents for Heavy Metals", Water Research, Vol.33, No.11, pp 2469-2479, 1999.

[6] Balkose, D. and Baltacioglu, H. "Adsorption of Heavy Metal Cations from Aqueous Solution by Wool Fiber", Journal of Chemical Technology and Biotechnology, Vol. 54, N0.4, pp 393-397, 1992.

[7] Shah, B. A., Shah, A. V. and Singh R. R. "Sorption Isotherms and Kinetics of Chromium Uptake from Wastewater using Natural Sorbent Material", International Journal of Environmental Science and Technology,Vol.6, No.1, pp 77-90, 2009.

[8] Rahmani, K., Mahvi, A. H., Vaezi, F., Mesdaghinia, A. R., Nabizade, R. and Nazmara, S. "Bioremoval of Lead by Use of Waste Activated Sludge", International Journal of Environmental Research,Vol. 3, No.3, pp 471-476, 2009.

[9] Inyang, M., Gao, B., Yao, Y., Xue, Y. W., Zimmerman, A. R., Pullammanappallil, P., and Cao, X. D. "Removal of Heavy Metals from Aqueous Solution by Biochars derived from Anaerobically Digested Biomass" Bioresource Technology, Vol. 110, pp5056, 2012.

[10]. Adil, S. Mashiatullah, A., Asma, M., Abid, J. and Ghaffar, A. "Heavy Metal Removal Efficiency of Paper Mulberry Biochar and Commercially Available Silica Powder from Simulated Industrial Wastewater". Iranica Journal of Energy \& Environment, Vol.5, No.4, pp 446-452, 2014.

[11] Zhang, Y. and Luo, W."Biochar from Digested Residues", BioResources, Vol. 9, No.2, pp 24842499, 2014.

[12] Tan, X. F., Liu, Y. G., Zeng, G. M., Wang, X., Hu, X.J., Gu, Y.L., and Yang, Z. Z. "Application of Biochar for The Removal of Pollutants from Aqueous Solutions", Chemosphere, Vol. 125,pp 70-85, 2015.

[13] Kumar, U. "Agricultural Products and ByProducts as a Low Cost Adsorbent for Heavy Metal Removal from Water and Wastewater: A Review", Scientific Research and Essays, Vol.1, No.2, pp033037, 2006.

[14] Wafwoyo, W., Seo, C. W. and Marshall W. E. "Utilization of Peanut Shells as Adsorbents for selected Metals", Journal of Chemical Technology and Biotechnology, Vol.74, pp1117-1121, 1999.

[15]Akpen, G. D., Nwaogazie, I.L. and Leton, T. G. "Adsorption Characteristics of Mango (Magnifera indica) Seed Shell Activated Carbon for Removing 
Phenol from Wastewater". Journal of Applied Science and Technology (JAST), Vol.19, Nos.1 \& 2, , pp43-48, 2014.

[16] Azhar, S. S., Liew. A. G., Suhardy, D., Hafiz, K. F. and Hatim, M. D. I. "Dye Removal from Aqueous Solution by using Adsorption on Treated Sugarcane Bagasse", American Journal of Applied Sciences, Vol. 11, pp1499-1503,2005.

[17] Kumar, U. and Bandyopadhyay. M. "Sorption of Cadmium from Aqueous Solution using PreTreated Rice Husk", Bio resource Technology, Vol. 97, pp.104-109, 2006.

[18] Argun, M. E., Dursun, S., Ozdemir, C. and Karatas, M. "Heavy Metal Adsorption by Modified Oak Sawdust: Thermodynamics and kinetics", Journal of Harzardous Materials. Vol. 141, pp77-85, 2007.

[19] Adewoye, L. T., Mustapha, S. I., Adeniyi, A. G., Tijani, J. O., Amoloye, M. A. and Ayinde, L. J. "Optimization of Nickel (ii) and Chromium (iii) Removal from Contaminated Water using Sorghum Bicolor", Nigerian Journal of Technology, Vol.36, No.3, pp 960-972, 2017.

[20] Lim, J., Kang, H., Kim, L. and Ko, S. "Removal of Heavy Metals by Sawdust Adsorption: Equilibrium and Kinetic Studies", Environmental Engineering Research, Vol. 13, No.2, pp 79-84, 2008.

[21] Mazumder, D.; Ghosh, D. and Bandyopadhyay, P. "Treatment of Electroplating Wastewater by Adsorption Technique", International Journal of Civil and Environmental Engineering, Vol.3, No.2, pp101-110, 2011.

[22] Rajeswari, M., Pushpa, A. "Continuous Biosorption of Arsenic by Moringa Olefera in a Packed Column", International Journal of Chemical Technology Research, Vol. 6, No.7, pp3603, 2014.

[23 Hasfalina C. B. M., Akinbile, C. O. and Jun, C. X. "Coconut Husk Adsorbent," BioResources, Vol.10, No.2, pp2859-2872, 2015.

[24] Akpen, G. D., Nwaogazie, I. L. and Leton, T. G. "Column Studies on the Removal of Chromium from Wastewater by Mango Seed Shell Activated Carbon", Journal of Science and Technology, Vol.35, No. 2, pp 1-12, 2015.

[25] Akpen, G. D., Aho, M. I. and Baba, N. "Preparation and Characterization of Activated Carbons from Albizia saman Pod", Journal of Science and Technology (JUST), Vol.36, No.3, pp44-53, 2016.

[26] Sharma, B., Singh, S., and Siddiqi, N. J. Biomedical Implications of Heavy Metals Induced Imbalances in Redox Systems. Biomedical Research International, Vol.2014, 2014, pp1-26, 2014.

[27] Hutchins, R. A. "New Simplified Design of Activated Carbon Systems", American Journal of Chemical Engineering, Vol. 80, No. 19, pp 133 138, 1973.
[28] Eckenfelder, W.W. Industrial Water Pollution Control. $2^{\text {nd }}$ edition, McGraw-Hill Book Company, Singapore, pp63-290, 1989.

[29] Bohart, G. S. and Adams, E. Q. "Behavior of Charcoal towards Chlorine", Journal of Chemical Society, Vol. 42, pp 523-529, 1920.

[30] Gimba, C. and Turoti, M. "Optimum Conditions for Carbonization of Coconut Shell", Scientifia Africana, Vol. 7, No. 2, pp.12 - 21, 2008.

[31] Baba, N. Adsorption of Cadmium from Wastewater by Albizia Saman Pod Activated Carbon. Unpublished M. Eng. Thesis, Department of Civil Engineering, University of Agriculture, Makurdi. Nigeria, 2016.

[32] Malik, R., Ramteke, D. S., Wate, S. R,. "Physicochemical and surface characterization of adsorbent prepared from groundnut shell by $\mathrm{ZnCl}_{2}$ activation and its ability to adsorb color". Indian Journal of Chemical Technology, Vol.13, pp319-28, 2006.

[33] Mdoe J, Mkayula L. "Preparation and characterization of activated carbons from rice husks and shell of palm fruits", Tanzania Journal of Science, Vol. 28, No.2, pp131-42, 2002.

[34] Akpen, G. D., Nwaogazie, I. L. and Leton, T. G. "Optimum Conditions for the Removal of Colour from Wastewater by Mango Seed Shell Based Activated Carbon", Indian Journal of Science and Technology, Vol. 4, No.8, pp 890-894, 2011.

[35] Wang, K Q., Chen, J. P., Chen, L., Wu, X. F., Su, X. J., Amartey, S., and Qin, W. "Isolation and IrradiationModification of Lignin Specimens from Black Liquor and Evaluation of their Effects on Wastewater Purification", BioResources, Vol. 9, No.4, pp6476-6489, 2014.

[36] Amarasinghe, B. M.W.P.K. "Lead and Cadmium Removal from Aqueous Medium using Coir Pith as Adsorbent: Batch and Fixed Bed Column Studies," Journal of Tropical Forestry and Environment, Vol.1, No.1, pp. 36-47, 2011.

[37] Hameed, B. H, "Removal of Cationic Dye from Aqueous solution using Jack Fruit Peel as NonConventional Low Cost Adsorbents", Journal of Hazardous Materials, Vol. 39, pp338-343, 2008.

[38] Benaissa, H. "Removal of Acid Dyes from Aqueous Solutions using Orange Peel as a Sorbent Material", Ninth International Water Technology Conference, IWTC9, Sharm El-Sheikh, Egypt, pp1175-1185, 2005.

[39] Kumar, U. and Acharya, J. "Fixed Bed Column Study for the Removal of Copper from Aquatic Environment by NCRH" Global Journal of Researches in Engineering-Chemical Engineering, Vol. 12, No. 3, pp1-5, 2012.

[40] Frank, H. and Altheon, S. C. Statistics-Concepts and Applications, Low Price Edition, Cambridge University Press, Great Britain, 727p, 1994. 